\title{
Tetrastyryl-Bodipy Dyes: Convenient Synthesis and Characterization of Elusive Near IR Fluorophores
}

2009

Vol. 11, No. 20 4644-4647

\section{Onur Buyukcakir, ${ }^{\dagger}$ O. Altan Bozdemir, ${ }^{\dagger}$ Safacan Kolemen, ${ }^{\ddagger}$ Sundus Erbas, ${ }^{\dagger}$ and Engin U. Akkaya ${ }^{\star,+, \ddagger}$}

Department of Chemistry and UNAM-Institute of Materials Science and Nanotechnology, Bilkent University, 06800 Ankara, Turkey

eua@fen.bilkent.edu.tr

Received August 18, 2009

\section{ABSTRACT}

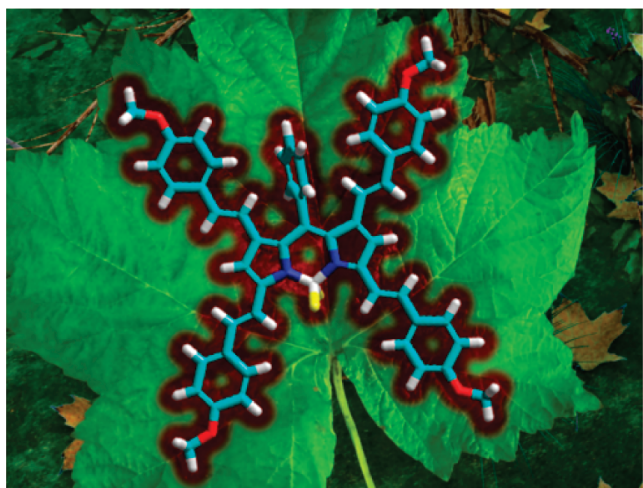

1,3,5,7-Tetramethyl-Bodipy derivatives undergo Knoevenagel-type condensations with aromatic aldehydes to ultimately yield tetrastyryl-Bodipy derivatives. The resulting dyes absorb and emit strongly in the near IR. As the versatility of the Bodipy dyes are fully appreciated, these new tetrastyryl dyes are likely to be featured in a variety of functional supramolecular systems.

For more than three decades after their initial synthesis, ${ }^{1}$ Bodipy dyes were known only as bright fluorescent dyes for use in cellular imaging as supplied by a few commercial sources. However, especially within the last five years, there has been a veritable Bodipy renaissance. ${ }^{2}$ This is in large part sparked by the new tactics ${ }^{3}$ in the functionalization of the Bodipy core, which led to the synthesis of longer wavelength absorbing/emitting fluorescent dyes, ${ }^{4}$ energy transfer cassettes, ${ }^{5}$ light harvesters,${ }^{6}$ sensitizers for solar cells ${ }^{7}$ and photodynamic therapy, ${ }^{8}$ nonlinear optical materials, ${ }^{9}$

UNAM-Institute of Materials Science and Nanotechnology.

Department of Chemistry. 208.

(1) Treibs, A.; Kreuzer, F. H. Justus Liebigs Ann. Chem. 1968, 718,

(2) (a) Ziessel, R.; Ulrich, G.; Harriman, A. New J. Chem. 2007, 31, 496-501. (b) Loudet, A.; Burgess, K. Chem. Rev. 2007, 107, 4891-4932. (c) Ulrich, G.; Ziessel, R.; Harriman, A. Angew. Chem., Int. Ed. 2008, 47, 1184-1201. mesogenic materials, ${ }^{10}$ supramolecular polymers, ${ }^{11}$ fluorescent chemosensors, ${ }^{12}$ and molecular logic systems. ${ }^{13}$ This remarkable versatility of Bodipy dyes, reminiscent of structurally related porphyrins, prompted Ziessel to label Bodipy as "porphyrin's little sister". 2c

The parent Bodipy unit has a major absorption peak $\left(\mathrm{S}_{0}-\mathrm{S}_{1}\right.$ transition) near $500 \mathrm{~nm}$; however, incorporation of fused aromatic rings and/or aryl substituents, ${ }^{4 \mathrm{~d}-\mathrm{i}}$ ethynylaryl substitution, ${ }^{14}$ and aza-substitution at the meso (8) position $^{4 \mathrm{~b}, \mathrm{c}, \mathrm{k}, 15}$ push this peak into the red end of the visible

(3) (a) Rurack, K.; Kollmannsberger, M.; Daub, J. Angew. Chem., Int. Ed. 2001, 40, 385-387. (b) Ulrich, G.; Goze, C.; Guardigli, M.; Roda, A.; Ziessel, R. Angew. Chem., Int. Ed. 2005, 44, 3694-3698. (c) Dost, Z.; Atilgan, S.; Akkaya, E. U. Tetrahedron 2006, 62, 8484-8488. (d) Rohand, T.; Baruah, M.; Qin, W.; Boens, N.; Dehaen, W. Chem. Commun. 2006, 266-268. (e) Li, L. L.; Han, J. Y.; Nguyen, B.; Burgess, K. J. Org. Chem. 2008, 73, 1963-1970. (f) Han, J. Y.; Gonzales, O.; Aguilar-Aguilar, A.; Pena-Cabrera, E.; Burgess, K. Org. Biomol. Chem. 2009, 7, 34-36. 
spectrum. All of these approaches may be useful in certain applications, nevertheless mono- and distyryl modifications seem to offer a greater degree of versatility as judged by the recent interest, ${ }^{7 b, c, 16}$ apart from our group. This clearly stems from the following facts: (i) Knoevenagel reaction of the 3- and 5-methyls is in most cases high yielding; (ii) the reaction conditions tolerate the use of a variety of aldehydes with different stereoelectronic characteristics; (iii) strong charge donor substituents are likely to yield switchable fluorescent molecules with internal charge transfer characteristics useful as chemosensors and molecular logic gates. $^{12,13}$

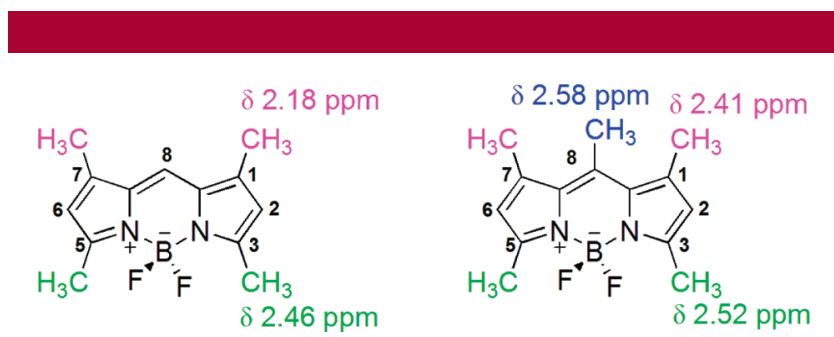

Figure 1. 1,3,5,7-Tetramethyl- and 1,3,5,7,8-pentamethyl-Bodipy derivatives; numbering and relevant ${ }^{1} \mathrm{H}$ NMR chemical shifts in $\mathrm{CDCl}_{3}$.

While considering the possibility of further functionalization of the Bodipy core, we carried out a Mulliken-charge analysis on the core carbon atoms of tetramethyl-Bodipy. The electron density of the carbon atoms varies in the following order: $2,6 \gg 1,7>3,5$.

(4) (a) Ito, S.; Murashima, T.; Ono, N.; Uno, H. Chem. Commun. 1998, 1661-1662. (b) Killoran, J.; Allen, L.; Gallagher, J. F.; Gallagher, W. M.; O'Shea, D. F. Chem. Commun. 2002, 1862-1863. (c) Zhao, W. L.; Carreira, E. M. Angew. Chem., Int. Ed. 2005, 44, 1677-1679. (d) Goze, C.; Ulrich, G.; Mallon, L. J.; Allen, B. D.; Harriman, A.; Ziessel, R. J. Am. Chem. Soc. 2006, 128, 10231-10239. (e) Thivierge, C.; Bandichhore, R.; Burgess, K. Org. Lett. 2007, 9, 2135-2138. (f) Goeb, S.; Ziessel, R. Org. Lett. 2007, 9, 737-740. (g) Umezawa, K.; Matsui, A.; Nakamura, Y.; Citterio, D.; Suzuki, K. Chem.-Eur. J. 2009, 15, 1096-1106. (h) Umezawa, K.; Nakamura, Y.; Makino, H.; Citterio, D.; Suzuki, K. J. Am. Chem. Soc. 2009, 130, 1550-1551. (i) Lager, E.; Liu, J.; Aguilar-Aguilar, A.; Tang, B. Z.; Pena-Cabrera, E. J. Org. Chem. 2009, 74, 2053-2058. (j) Chen, J.; Mizumura, M.; Shinokubo, H.; Osuka, A. Chem.-Eur. J. 2009, 15, 59425949. (k) Loudet, A.; Bandichhor, R.; Wu, L. X.; Burgess, K. Tetrahedron 2008, 64, 3642-3654.

(5) (a) Harriman, A.; Mallon, L.; Ziessel, R Chem.-Eur. J. 2008, 14, 11461-11473. (b) Barin, G.; Yilmaz, M. D.; Akkaya, E. U. Tetrahedron Lett. 2009, 50, 1738-1740. (c) Diring, S.; Puntoriero, F.; Nastasi, F.; Campagna, S.; Ziessel, R. J. Am. Chem. Soc. 2009, 131, 6108-6109.

(6) (a) Yilmaz, M. D.; Bozdemir, O. A.; Akkaya, E. U. Org. Lett. 2006, 8, 2871-2873. (b) Yuan, M.; Yin, X.; Zheng, H.; Ouyang, C.; Zuo, Z.; Liu, H.; Li, Y. Chem. Asian J. 2009, 4, 707-713.

(7) (a) Ertan-Ela, S.; Yilmaz, M. D.; Icli, B.; Dede, Y.; Icli, S.; Akkaya, E. U. Org. Lett. 2008, 10, 3299-3302. (b) Rousseau, T.; Cravino, A.; Bura, T.; Ulrich, G.; Ziessel, R.; Roncali, J. Chem. Commun. 2009, 1673-1675. (c) Rousseau, T.; Cravino, A.; Bura, T.; Ulrich, G.; Ziessel, R.; Roncali, J. J. Mater. Chem. 2009, 19, 2298-2300.

(8) (a) Gorman, A.; Killoran, J.; O'Shea, C.; Kenna, T.; Gallagher, W. M.; O'Shea, D. F. J. Am. Chem. Soc. 2004, 126, 10619-10631. (b) Atilgan, S.; Ekmekci, Z.; Dogan, A. L.; Guc, D.; Akkaya, E. U. Chem. Commun 2006, 4398-4390.

(9) (a) Singh-Rachford, T. N.; Haefele, A.; Ziessel, R.; Castellano, F. N. J. Am. Chem. Soc. 2008, 130, 16164-16165. (b) Bouit, P. A.; Kamada, K.; Feneyrou, P.; Berginc, G.; Toupet, L.; Maury, O.; Androud, C. Adv. Mater. 2009, 21, 1151-1154.

(10) Camerel, F.; Bonardi, L.; Schmutz, M.; Ziessel, R. J. Am. Chem. Soc. 2006, 128, 4548-4549.

(11) Bozdemir, O. A.; Buyukcakir, O.; Akkaya, E. U. Chem.-Eur. J. 2009, 15, 3830-3838.
The results suggested that the methyl groups in positions 1 and 7 could be almost as acidic as 3,5-methyls. ${ }^{1} \mathrm{H}$ NMR

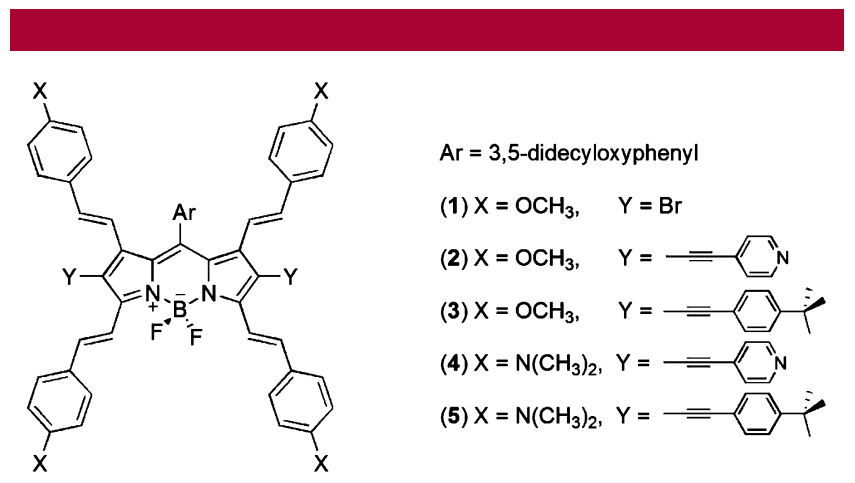

Figure 2. Structures of the quadruple Knoevenagel reaction products 1-5.

spectra should provide additional support for this argument; however, the correlation between acidity and the chemical shifts is problematic due to magnetic anisotropy effects. In the 8-phenyl-substituted Bodipy dyes, 1,7-methyls are in the shielding zone of the phenyl substituents and experience a shielding by approximately $0.7 \mathrm{ppm}$. The situation is more revealing in the tetramethyl and pentamethyl derivatives lacking the phenyl substituent (Figure 1). The chemical shifts for two sets of methyl protons $(3,5$ and 1,7$)$ resonate closely especially in the pentamethyl derivative, which could be interpreted as a sign of comparable acidity. Encouraged by these observations, we looked for likely conditions to extend Knoevenagel condensation to other methyl substituents on the Bodipy core. Our earlier experience with the distyryls led us to start with Bodipy dyes with electron-withdrawing substituents, as they clearly enhance the acidity of the methyl substituents.

Thus, the first dye we chose for a quadruple Knoevenagel reaction was a Bodipy derivative carrying pyridinylethynyl substituents on the 2,6-positions ( $\mathrm{Y}=4$-pyridinylethynyl),

(12) (a) Coskun, A.; Akkaya, E. U. J. Am. Chem. Soc. 2006, 128, 14474 14475. (b) Yuan, M. J.; Li, Y. L.; Li, J. B.; Li, C. H.; Liu, X. F.; Lv, J.; Xu, J. L.; Liu, H. B.; Wang, S.; Zhu, D. Org. Lett. 2007, 9, 2313-2316. (c) Atilgan, S.; Ozdemir, T.; Akkaya, E. U. Org. Lett. 2008, 10, 4065-4067. (d) Lee, H. Y.; Bae, B. R.; Park, J. C.; Song, H.; Han, W. S.; Jung, J. H. Angew. Chem., Int. Ed. 2009, 48, 1239-1243. (e) Qi, X.; Kim, S. K.; Han, S. J.; Xu, L.; Jee, A. Y.; Kim, H. N.; Lee, C.; Kim, Y.; Lee, M.; Kim, S. J.; Yoon, J. Tetrahedron Lett. 2008, 49, 261-264. (f) Guliyev, R.; Coskun, A.; Akkaya, E. U. J. Am. Chem. Soc. 2009, 131, 9007-9013.

(13) (a) Coskun, A.; Deniz, E.; Akkaya, E. U. Org. Lett. 2005, 7, 51875189. (b) Yuan, M.; Zhou, W.; Liu, X.; Zhu, M.; Li, J.; Yin, X.; Zheng, H.; Zuo, Z.; Ouyang, C.; Liu, H.; Li, Y.; Zhu, D. J. Org. Chem. 2008, 73, 5008-5014. (c) Ozlem, S.; Akkaya, E. U. J. Am. Chem. Soc. 2009, 131, 48-49.

(14) (a) Rohand, T.; Qin, W.; Boens, N.; Dehaen, W. Eur. J. Org. Chem. 2006, 4658-4663. (b) Bozdemir, O. A.; Buyukcakir, O.; Akkaya, E. U. Chem.-Eur. J. 2009, 15, 3830-3838.

(15) Coskun, A.; Yilmaz, M. D.; Akkaya, E. U. Org. Lett. 2007, 9, 607609.

(16) (a) Liu, J.-Y.; Ermilov, E. A.; Roder, B. Chem. Commun. 2009, 1517-1519. (b) Niu, S. L.; Ulrich, G.; Ziessel, R.; Kiss, A.; Renard, P.-Y.; Romieu, A. Org. Lett. 2009, 11, 2049-2052. (c) Wenwu, Q.; Baruah, M.; Sliwa, M.; van der Auweraer, M.; de Borggraeve, W. M.; Beljonne, D.; van Averbeke, B.; Boens, N. J. Phys. Chem. A 2008, 112, 6104-6114. (d) Diring, S.; Puntoriero, F.; Nastasi, F.; Campagna, S.; Ziessel, R. J. Am. Chem. Soc. 2009, 131, 6108-6109. 
and the aromatic aldehyde was $p$-anisaldehyde (Figure 2). The reaction conditions were similar to mono- and distyryl functionalizations (Supporting Information). A similar reaction with a Bodipy derivative which has 4-t-butylphenylethynyl substituents on the 2,6-positions produced expected tetrastyryl product $\mathbf{3}$, requiring a slightly longer time under reflux for full conversion. It is also interesting to note that Knoevenagel condensations of this kind have been carried out with tetramethyl-substituted Bodipy's for almost a decade, but until now, no one has identified triple or quadruple condensation products.

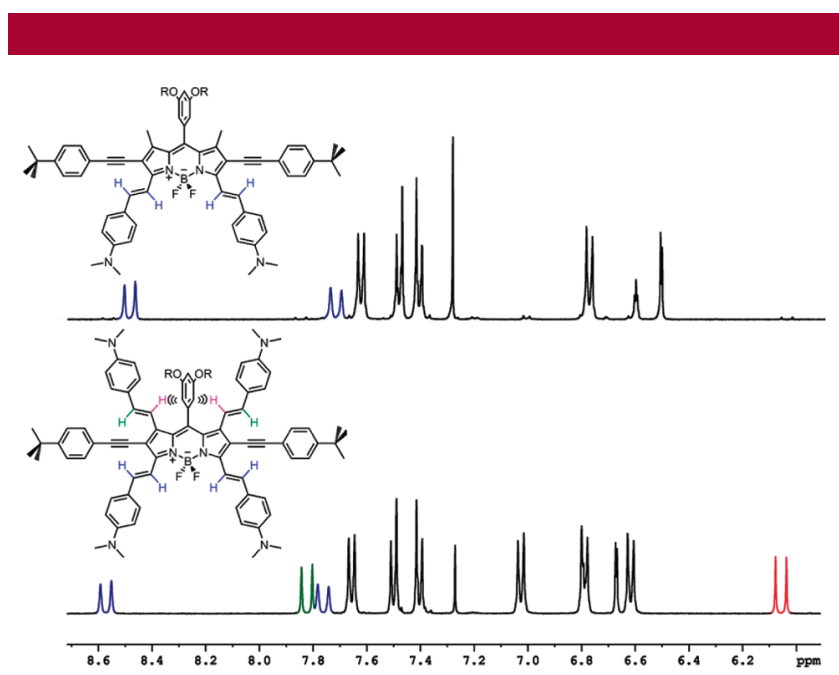

Figure 3. Structures and partial ${ }^{1} \mathrm{H}$ NMR spectra of the distyryl (top) and the tetrastyryl-Bodipy $\mathbf{5}$ (bottom). A significant upfield shift of one pair (color coded in red) of trans-vicinally coupled protons due to their protrusion toward the meso-phenyl ring is obvious. It is a signature feature for 8-phenyl-substituted tetrastyrylBodipy's. The other pair (green) is not affected.

Knoevenagel reaction introduces styryl groups exclusively in a trans $(E)$ configuration. In distyryl compounds, this is easily evidenced by the existence of two pairs of transcoupled protons with a chemical shift difference of approximately $1 \mathrm{ppm}$. In the tetrastyryl compounds, there are two additional pairs of protons showing peaks around 7.7 and $6.1 \mathrm{ppm}$. Figure 3 shows the aromatic regions of the ${ }^{1} \mathrm{H}$ NMR spectra of the tetrastyryl-bodipy $\mathbf{5}$ and the intermediate distyryl-bodipy for comparison. The integration ratios and the upfield shift of one pair of ethylenic protons are in accordance with the structure of the tetrastyryl dyes.

To gain insight into the scope of the reaction, we tried the reaction with bromo-substituents and with no substituents on the 2,6-positions. The 2,6-dibromo derivative reacted as efficiently as the ethynyl-substituted derivatives to yield the tetrastyryl compound. 2,6-H Bodipy derivative 6, as expected, reacted slowly, but this allowed us a remarkable feat. By simply stopping the reaction at different times, we could easily isolate mono-, di-, tri-, and tetrastyryl derivatives as the major products (Figure 4). This fact alone should give a hint to the versatility of this reaction. The absorption and the emission spectra of this series of Bodipy dyes (7-10) are shown in Figure 5. It is also interesting to note that the

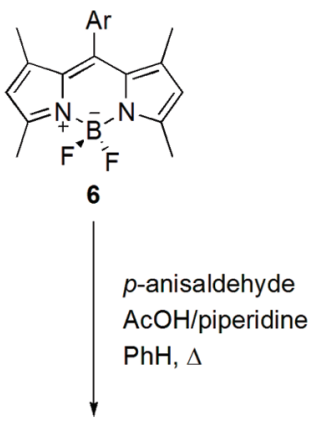

$\mathrm{Ar}=$ 3,5-didecyloxyphenyl
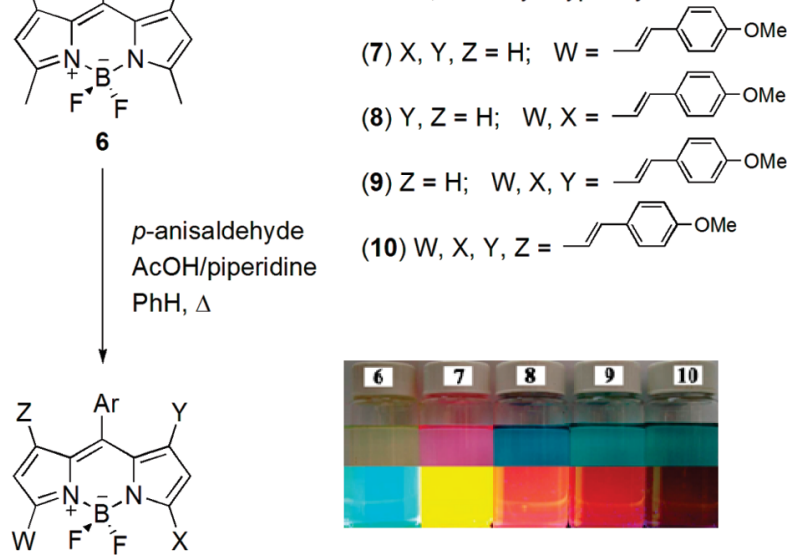

Figure 4. One-pot synthesis of four different styryl-Bodipy dyes. The reactions can be stopped at appropriate times to maximize the yield for a particular derivative. The inset picture shows the colors under ambient light (top half) and when excited using a hand-held UV lamp at $360 \mathrm{~nm}$ (bottom half).
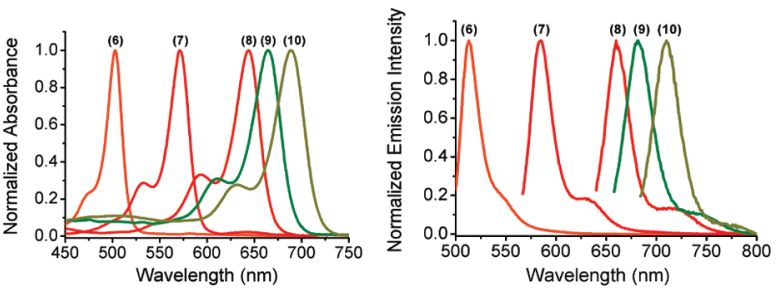

Figure 5. Absorption and emission spectra of the compounds 6-10.

first methyls to react are exclusively 3,5-methyls, and triand tetra-substituted products are obtained only when the concentration of all the reactants is increased by the removal of most of the solvent. Thus, by simple condensation reactions, the absorption peak of a Bodipy dye $\mathbf{6}$ can be pushed stepwise from 498 to $572,645,665$, and $689 \mathrm{~nm}$. Next, we wanted to demonstrate that the reaction is not limited to $p$-anisaldehyde. Condensation with $p$ - N,N-dimethylaminobenzaldehyde also proceeds smoothly. The spectroscopic data for the new tetrastyryl-Bodipy dyes are presented in Table 1 . The tetrastyryl dyes $\mathbf{4}$ and $\mathbf{5}$ are true near IR dyes, absorbing maximally around $800 \mathrm{~nm}$ and emitting maximally around $835 \mathrm{~nm}$ in chloroform. The peaks are also relatively sharp as judged by the less than $50 \mathrm{~nm}$ fwhm (full-width at half-maximum) values. The dyes have very large extinction coefficients rivaling those of typical cyanine dyes. Their quantum yields were also found to be moderate to high, except for dimethylaminostyryl dye $\mathbf{5}$. The strong charge transfer and highly polar excited states in $\mathbf{4}$ and $\mathbf{5}$ tend to decrease the emission quantum yield, so this is not unexpected.

Bodipy dyes proved to be more than simple fluorophores. We are confident that such straightforward functionalization and derivatization methodologies are likely to add to their 
Table 1. Spectral Data for Tetrastyryl-Bodipy Dyes and Selected Intermediate Dyes Isolated from the Knoevenagel Reaction Media

\begin{tabular}{ccccr}
\hline compound $^{a}$ & $\lambda_{\text {abs }}(\mathrm{nm})$ & $\lambda_{\text {em }}(\mathrm{nm})$ & $\Phi_{\mathrm{f}}^{b}$ & \multicolumn{1}{c}{$\varepsilon_{\max }{ }^{c}$} \\
\hline $\mathbf{1}$ & 700 & 727 & 0.12 & 48800 \\
$\mathbf{2}$ & 721 & 747 & 0.42 & 88200 \\
$\mathbf{3}$ & 732 & 756 & 0.23 & 173900 \\
$\mathbf{4}$ & 802 & 837 & 0.13 & 141500 \\
$\mathbf{5}$ & 797 & 835 & 0.05 & 144700 \\
$\mathbf{7}$ & 572 & 585 & 0.92 & 58900 \\
$\mathbf{8}$ & 645 & 660 & 0.37 & 116400 \\
$\mathbf{9}$ & 665 & 682 & 0.35 & 96900 \\
$\mathbf{1 0}$ & 689 & 710 & 0.34 & 127900 \\
${ }^{a}{\text { Data acquired in } \mathrm{CHCl}_{3} \text { in dilute solutions. }}^{b}$ Relative quantum yields. \\
${ }^{c}{\text { Unit: } \mathrm{cm}^{-1} \mathrm{M}^{-1} \text {. }}$
\end{tabular}

impressive versatility. It appears that by fine-tuning the reaction conditions it should be possible to tether four different styryl groups to the Bodipy core. Needless to say, these novel and easily accessible chromophores are expected to make an impact as sensitizers for photodynamic therapy and dye sensitized solar cells, as structural units in dendritic light harvesters, and as versatile building blocks in highly structured supramolecular entities. Setting aside the reversible oxygen carrying function, it appears that the new generation of Bodipy dyes is poised to compete with porphyrins as one of the prime building blocks in supramolecular chemistry. Our work along these lines is in progress.

Acknowledgment. Financial support by the Turkish Academy of Sciences (TÜBA) is gratefully acknowledged. S.E. thanks TUBITAK for a scholarship.

Supporting Information Available: Experimental procedures, structural proofs, and spectral data for all new compounds are provided. This material is available free of charge via the Internet at http://pubs.acs.org.

OL9019056 